\title{
Optimization and Validation of RP-HPLC-UV/VIS Method for Determination Some Antioxidants in Dry Calyces of Iraqi Hibiscus Sabdraffia Linn
}

\author{
Sarah K. Ibrahim*
}

Kareem D. Khalaf*

Received 25, February, 2014

Accepted 13, May, 2014

\begin{abstract}
:
A new (Reversed Phase- High Performance Liquid chromatography) RP-HPLC method with Ultraviolet-Visible spectrophotometry has been optimized and validated for the simultaneous extraction and determination of antioxidants present in Iraqi calyces of Hibiscus Sabdraffia Linn. The method is based on using ultrasonic bath for extracting antioxidants. Limit of detection in $\mu \mathrm{g} / \mathrm{ml}$ of Vitamin C, Sabdaretine, Gossypetine, Hibiscetine, Anthocyanins, Dephinidin-3-glucoside were113.8294 $\times 10^{-}$ ${ }^{6}, 123.0453 \times 10^{-6}, 70.3681 \times 10^{-6}, 59.6730 \times 10^{-6}, 148.1710 \times 10^{-6}$, and $125.3481 \times 10^{-6}$ respectively. The concentration of antioxidants found in dry spacemen of calyces of Iraqi Hibiscus Sabdraffia Linn. under study: Vitamin C, Sabdaretine, Gossypetine, Hibiscetine, Anthocyanins, and Dephinidin-3-glucoside are $258.3 \mu \mathrm{g} / \mathrm{g}, 225.51 \mu \mathrm{g} / \mathrm{g}$, $154.975 \mu \mathrm{g} / \mathrm{g}, 111.407 \mu \mathrm{g} / \mathrm{g}, 439.442 \mu \mathrm{g} / \mathrm{g}$, and $185.729 \mu \mathrm{g} / \mathrm{g}$ respectively.
\end{abstract}

\section{Key words: antioxidants, Hibiscus Sabdraffia Linn.}

\section{Introduction:}

Hibiscus Sabdraffia Linn. is a tropical plant and it belongs to malvacae family[1]. Calyces are important part of Hibiscus Sabdraffia Linn.it was found that when calyces is dried under sun light and air, contain organic acids ( tartaric, citric, malic, and hibiscic) showing high stability under the mentioned drying process [2]. Many biological activity studies were conducted on $\mathrm{H}$. sabdariffa and some of these compounds have been shown to have antibacterial, antifungal, antihypertensive, anti-inflammatory, antioxidant, antispasmodic, antitumor and hypoglycaemic [3] activities. Medical uses of Calyces are wide. Infusion of Calyces are regarded as diuretic, choleretic, febrifugal, hypotensive, decreasing the viscosity of blood and stimulating intestinal peristalsis [4], reduce hypertenstion [5]. Infusions of calyces are used as antiseptic, aphrodisiac, astringent,

cholagogue, demulcent, diuretic, emollient, purgative, refreshment, sedative, stomachic, and tonic, traditionally [6]. Water extract of calyces is used for its astringent and digestive properties and also used for treating different type of cancer and reducing high cholestrol [7]. Calyx extract has also been used as an effective treatment for patients with kidney stones due to its uricosuric effect [8]. The red calyces contain antioxidants including flavonoids (gossypetine, hibiscetine, sabdaretine) [9], anthocyanins and vitamin C[10]. Calyx of Hibiscus Sabdariffa Linn. Contain also different anthocyanins as delphinindin-3-glucoside, delphinidin3-xyloglucoside, delphinidin-3sambubioside, cyaniding-3xyloglucoside [11]. The antioxidants under study were considered as strong scavengers of free radicals which are unstable chemical species that react

*Department of Chemistry, College of Science for Women, University of Baghdad (Iraq) 
rapidly [12] with other chemical species in a biological system. Reactive species, such as superoxides $\left(\mathrm{O}_{2}{ }^{--}\right.$and $\left.\mathrm{OOH}\right)$, hydroxyl $\left(\mathrm{OH}^{\circ}\right)$, and peroxyl(ROO) radicals, can attack stable molecules in a healthy organism and produce illnesses[13]. Antioxidants can react with the radical, but rather than turning into another reactive molecule, these compounds are relatively stable in the presence of the radical electron. As a consequence, they scavenge the radical electrons, quench the chain reaction, and avoid further damage. The relative stability of antioxidants containing a radical electron is generally the result of the presence of conjugated bonds, so that the radical electron can be delocalized. As a consequence, aromatic compounds in general, and phenolic compounds in particular are very effective antioxidants [14].

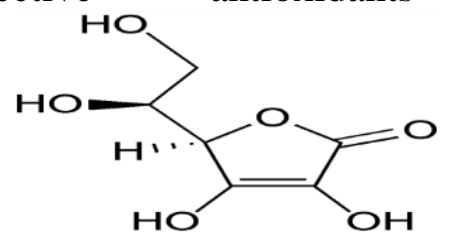

1. Vitamin $\mathrm{C}$
Antioxidants provide protection against degenerative diseases. Such as cancer, hipercholestrol and coronary heart disease [15].

Reversed phase HPLC with UV/ Vis detector (RP-HPLC-UV/Vis) is an important analytical technique with strong chromospheres that absorb light in the wavelength region from $200 \mathrm{~nm}$ to $800 \mathrm{~nm}$ [16]. The objective of study is to simultaneous extraction, separation and determination of some antioxidants from calyces of Iraqi Hibiscus Sabdraffia Linn. by using modern technique of RP- HPLC- UV/ Visible detection technique. Antioxidants understudy are 1.Vitamin C, 2.Gossypetine, 3.Hibiscetine, 4.Delphinindin-3-glucoside,

5.Anthocyanins (as total), and 6.Sabdaretine (unknown structure) (see Figure 1)

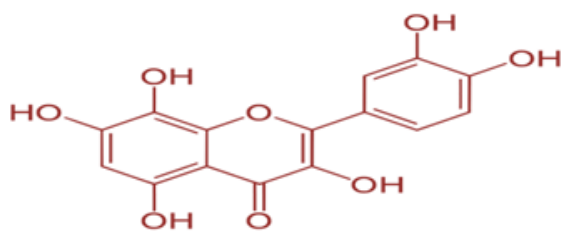

2. Gossypetine

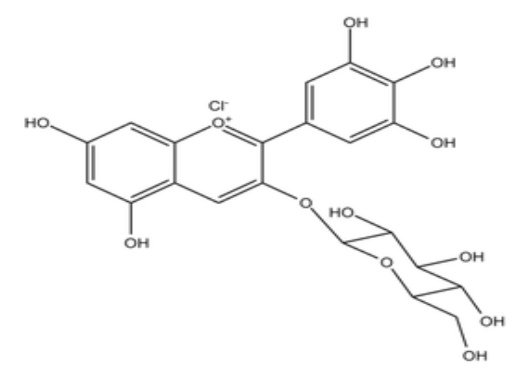

4. Deiphinindin-3-glucoside

3. Hibiscetine

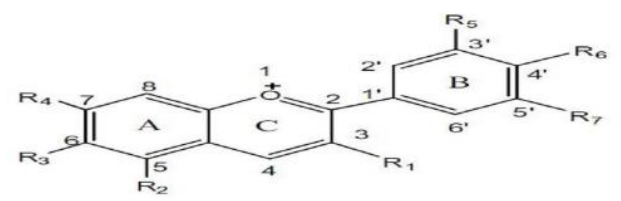

5. Anthocyanins

$\mathrm{R} 1=\mathrm{O}$-sugare (glucose, arabinose, galactose).

$\mathrm{R} 2, \mathrm{R} 4, \mathrm{R} 6=\mathrm{OH}, \mathrm{R} 3, \mathrm{R} 5$ and $\mathrm{R} 7=\mathrm{H}, \mathrm{OH}, \mathrm{OCH}_{3}$

Fig.1: The Structure of Antioxidants in Calyces of Hibiscus Sabdraffia Linn.

Ijeoah et al. [17] evaluated total anthocyanin, total polyphenol, and ascorbic acid (vitamin C) contents in
Hibiscus sabdraffia from Nigeria. Total anthocyanin contant was evaluated using the method of Fuleki and Francis 
(1969). Anthocyanin content in this evaluation was $1.15 \mathrm{mg} / \mathrm{g}$. total phenolic content was evaluated by using (Singleton et al, 1990) method. The total polyphenol content was 1.10 $\mathrm{mg} / \mathrm{g}$. the ascorbic acid contant of the sample was evaluated using AOAC (2000) method. The content of ascorbic acid was $16.7 \mathrm{mg} / \mathrm{g}$.

\section{Materials and Methods:}

\section{Hibiscus Sabdariffa Linn. sample.}

Fresh Hibiscus Sabdariffa Linn. fruits were harvested from Baghdad, Iraq. After harvesting the fruits were washed with deionized water three times to clean them from dust, then seeds were removed to obtain fresh Hibiscus Sabdariffa Linn. calyces. Fresh Hibiscus Sabdariffa Linn. calyces were dried at a room temperature for 7 days. Dried Hibiscus Sabdariffa Linn. calyces were immediately packed in polyethylene jars. Dried Hibiscus Sabdariffa Linn. calyces also dried in oven at $35 \mathrm{C}^{\circ}$ for three hours until constant weight. Dryness Hibiscus Sabdariffa Linn. calyces were ground for $10 \mathrm{~min}$ using Agate mortar. The calyces powder were immediately packed in polyethylene jars and kept in refrigerator until used.

\section{Chemicals.}

All chemical reagents used for analysis antioxidants by RP- HPLC- UV/Vis were analytical Grad (99.99\%) of BDH Company. The reagents include Acetonitrile, Deionize water, and Methanol. Standards of (1) Vitamin C (99.99\%), (2) Gossypetin (99.9\%), (3) Hibiscetin (99.9\%), (4) Sabdaretine (99.9\%), (5) Anthocyanins (99.8\%), and (6) Delphinidin-3-glucoside (99.9\%) were purchased from $\mathrm{BDH}$ Company.

\section{Preparation of Standard Solution.}

Preparation of standard stock and working solution are carried out by the following method. To prepare 1000 ppm stock standard of any antioxidants, 1 gram was transferred into a volumetric flask of $1000 \mathrm{ml}$ and diluted to mark by using deionized water. A quantity of $10 \mathrm{ml}$ is pipetted from the above stock solution and transferred into a volumetric flask of $100 \mathrm{ml}$ and diluted with deionized water to the mark in order to obtain $100 \mathrm{ppm}$. A working standard solution is prepared by transferring of $25 \mathrm{ml}$ of diluted standard solution in a volumetric flask of $100 \mathrm{ml}$ and diluted to the mark with deionized water to obtain a working standard solution of $25 \mathrm{ppm}$. These working standard solutions were kept refrigerated in ambered containers.

\section{Extraction Procedure.}

Calyces liquid extracts were carried by using deionized water: methanol solutions in different ratio, table (1), were used for the extraction. Calyces powder (1 g) was placed in glass beakers, and $10 \mathrm{ml}$ of extracting agent was added. The beakers were placed in the Ultra sonic bath for $15 \mathrm{~min}$, the mixtures were allowed to stand for 5 min. The supernatant was filtered through Whatman paper No.2 and also filtered through micro filter $(0.45 \mu \mathrm{m})$. The filtrate was kept in polyethylene tubes and preserved in fridge.

\section{Table (1): Different Deionized Water- Methanol Ratio Used in} Extraction.

\begin{tabular}{|c|c|c|}
\hline \multirow{2}{*}{ Samples } & \multicolumn{2}{|c|}{ Deionized water- methanol ratio } \\
\cline { 2 - 3 } & $\begin{array}{c}\text { Deionized } \\
\text { water\% }\end{array}$ & Methanol\% \\
\hline Sample 1 & 100 & 0 \\
\hline Sample 2 & 80 & 20 \\
\hline Sample 3 & 60 & 40 \\
\hline Sample 4 & 50 & 50 \\
\hline Sample 5 & 40 & 60 \\
\hline Sample 6 & 20 & 80 \\
\hline Sample 7 & 0 & 100 \\
\hline
\end{tabular}

\section{HPLC Analysis.}

The quantitative and qualitative analysis of antioxidants was performed 
on Shimadzu HPLC system model LC6A equipped with two pumps as solvent delivery model LC-10A from Shimadzu Corporation and A Shimdzu SPD-6A ultraviolet -visible variable wave length (190-800 nm) detector. 20 $\mu \mathrm{l}$ samples was injected, and the chromatographic separation was performed on a $\mathrm{RP}-\mathrm{C}_{18}$ Phenomenex (3 $\mu \mathrm{m})$ column, $50 \mathrm{~mm} \times 4.6 \mathrm{~mm}$. After optimizing the instrumental and sample parameter, the HPLC analysis condition for the sample were Deionized water acidified with acetic $\operatorname{acid}(0.1) \%$ and Acetonitrile (20:80)\% as mobile phase, $1.0 \mathrm{ml} / \mathrm{min}$ as flow rate, and using $254 \mathrm{~nm}$ as maximum wavelength.

\section{Results and Discussion :}

1. Optimization of Organic Modifiers of Mobile Phase in Reversed Phase HPLC.

This study was done by using deionized water acidified with acetic acid $(0.1 \%)$ and acetonitrile in different ratio, this stage was done by system of
HPLC. So, in order to study the effect of acetonitrile as an organic modifier on the separation efficiency, several experiments were carried out through changing the quantities of acidified deionized water and acetonitrile as following (Table 2) : (100\%:0\%, 95\%: 5\%, 90\%: 10\%, 80\%: 20\%, 75\%: $25 \%$, 70\%: $30 \%$, and 65\%: $35 \%$ as acidified deionized water: acetonitrile). During the optimization process, it was found that on using $0 \%, 5 \%$ and $10 \% \mathrm{ACN}$, the obtained base line is very noisy, wide peak shape and tailed except Sabdaretine and Dephinidin-3glucoside showed a symmetrical peak especially in $0 \%$ ACN. In $25 \%, 30 \%$ and $35 \%$ ACN, showed a good base line, but the peaks of anthocyanins and Dephinidin-3-glucoside showed a symmetrical peaks at $30 \%$ ACN. At $35 \%$ ACN Vitamin $\mathrm{C}$ and Gossypetine showed also a symmetrical peak. Finally it was found that on using $20 \%$ ACN and $0.1 \%$ acetic acid provide a good resolution as shown in Figure (2).

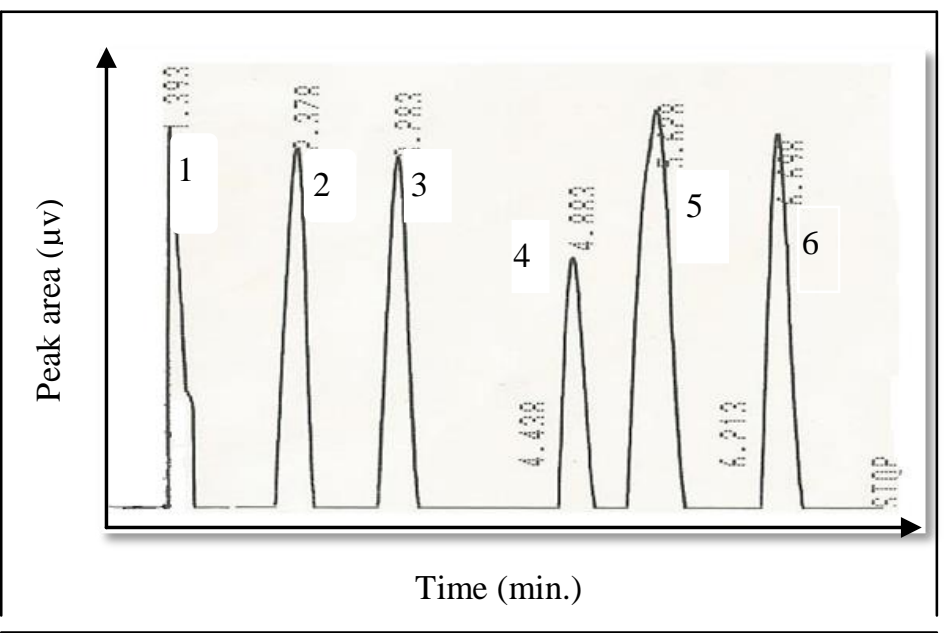

Fig. 2: As a mobile phase chromatogram Separation of Antioxidants using $20 \% \mathrm{ACN}$, the sequence of the peaks is as follow: 1.Vitamin C, 2. Sabdaretine, 3. Gossypetine, 4.Hibiscetine, 5.Anthocyanins, 6.Dephinidin-3-glucoside. 
Table 2: The Effect of Organic Modifier on RT and Peak Area of Antioxidant.

\begin{tabular}{|c|c|c|c|}
\hline Antioxidant & Acetonitrile \% & Retention time (min.) & Peak area $(\mu v)$ \\
\hline \multirow{7}{*}{ Vitamin $C$} & 0 & 1.883 & 30764 \\
\hline & 5 & 1.617 & 25751 \\
\hline & 10 & 1.638 & 28406 \\
\hline & 20 & 1.393 & 19793 \\
\hline & 25 & 1.242 & 26358 \\
\hline & 30 & 1.142 & 33081 \\
\hline & 35 & 1.022 & 21831 \\
\hline \multirow{7}{*}{ Sabdaretine } & 0 & 2.618 & 25947 \\
\hline & 5 & 2.462 & 9427 \\
\hline & 10 & 2.328 & 24418 \\
\hline & 20 & 2.378 & 19932 \\
\hline & 25 & 2.155 & 14266 \\
\hline & 30 & 1.922 & 30414 \\
\hline & 35 & 1.81 & 35571 \\
\hline \multirow{7}{*}{ Gossypetine } & 0 & 3.772 & 37753 \\
\hline & 5 & 4.14 & 25014 \\
\hline & 10 & 3.35 & 35716 \\
\hline & 20 & 4.883 & 13164 \\
\hline & 25 & 3.082 & 14516 \\
\hline & 30 & 2.758 & 30382 \\
\hline & 35 & 2.642 & 18506 \\
\hline \multirow{7}{*}{ Hibiscetine } & 0 & 6.748 & 43167 \\
\hline & 5 & 7.115 & 33648 \\
\hline & 10 & 4.56 & 3695 \\
\hline & 20 & 4.883 & 13164 \\
\hline & 25 & 4.9 & 24541 \\
\hline & 30 & 3.413 & 29166 \\
\hline & 35 & 3.29 & 25757 \\
\hline \multirow{7}{*}{ Anthocyanins } & 0 & 8.388 & 55675 \\
\hline & 5 & 8.1 & 2446 \\
\hline & 10 & 5.442 & 43105 \\
\hline & 20 & 5.628 & 21424 \\
\hline & 25 & 5.82 & 14135 \\
\hline & 30 & 3.928 & 44685 \\
\hline & 35 & 3.8 & 27887 \\
\hline \multirow{7}{*}{$\begin{array}{l}\text { Dephinidin-3- } \\
\text { glucoside }\end{array}$} & 0 & 10.37 & 15759 \\
\hline & 5 & 8.573 & 41957 \\
\hline & 10 & 7.467 & 32284 \\
\hline & 20 & 6.698 & 14992 \\
\hline & 25 & 6.07 & 5615 \\
\hline & 30 & 4.39 & 29380 \\
\hline & 35 & 4.283 & 27574 \\
\hline
\end{tabular}

2. The Effect of Extraction Mixture on Extraction of Antioxidants.

Seven kinds of solvent extracts from calyces of H. Sabdraffia Linn. were used to examine the effects of extraction solvent mixtures on antioxidant concentration. All calyx extracts are rich source in antioxidants but the best extraction occurs in 100\% deionized water: $0 \%$ methanol as extraction agent. Figure 3 shows the best separation.

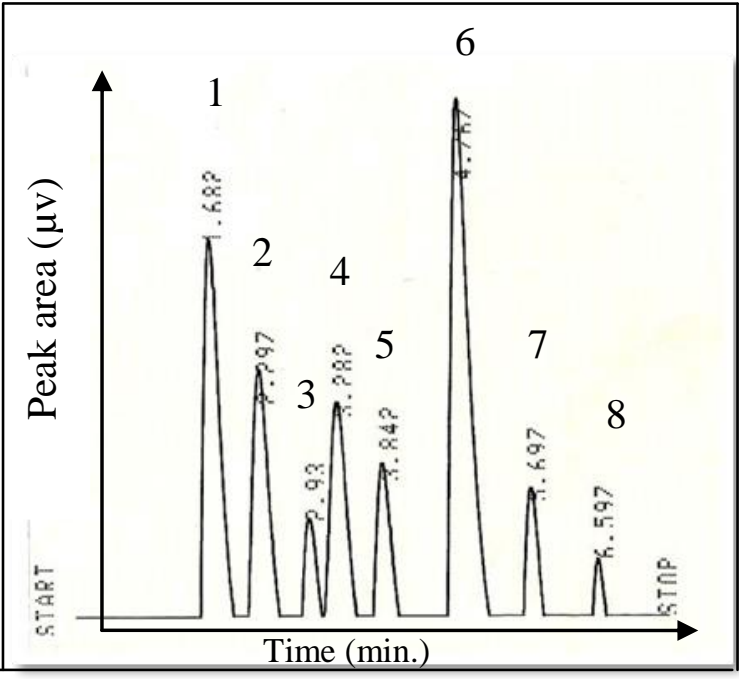

Fig. 3: The Best Separation of Antioxidant in Calyces Sample. 
According to above figure and retention time, the sequence of the peaks is as follow: 1.Vitamin C, 2 . Sabdaretine, 3.Unknown peak, 4. Gossypetine, 5.Hibiscetine, 6.Anthocyanins, 7.Dephinidin-3glucoside, 8. Unknown peak.

\section{Validation Method}

The validation study for Vitamin $C$, Sabdaretine, Gossypetine, Hibiscetine, Anthocyanins, and Dephinidin-3glucoside using RP-HPLC-UV/Vis was performed under the optimized conditions at $254 \mathrm{~nm}$ as maximum wavelength, $1.0 \mathrm{ml} / \mathrm{min}$ as flow rate of mobile phase, and mixture phase $\mathrm{A}$ (acidified deionized water) with phase
$\mathrm{B}$ (acetonitrile) as a mobile phase with elution ratio (80A: $20 \mathrm{~B}$; v/v) during analysis time ( 7 minutes).

\section{Linearity and Limit of Detection (LOD).}

Six standards solutions of antioxidants were prepared in the following concentration: $25,12.5,6.25,3.25$, 1.62 and, 0.78 in $\mu \mathrm{g} / \mathrm{ml}$. The calibration curve obtained by plotting the peak area of chromatograms for antioxidants against the concentration, with three replicates $(n=3)$. Table 3 shows the validation of analytical method obtained from the calibration curves of antioxidants analysed on RPHPLC-UV/Vis.

Table 3: Validation of analytical method for antioxidants by RP-HPLC-UV/Vis.

\begin{tabular}{|c|c|c|c|c|}
\hline Antioxidants & Calibration equation & $\mathrm{R}^{2}$ & $\mathrm{RSD} \%$ & $\mathrm{LOD}(\mu \mathrm{g} / \mathrm{ml})$ \\
\hline Vitamin C & $\mathrm{Y}=2530.1 \mathrm{x}+148.5$ & 0.9980 & 0.013334 & $113.8294 \times 10^{-6}$ \\
\hline Sabdaretine & $\mathrm{Y}=2340.6 \mathrm{x}+5281$ & 0.9914 & 0.008592 & $123.0453 \times 10^{-6}$ \\
\hline Gossypetine & $\mathrm{Y}=3240.1 \mathrm{x}+917.27$ & 0.9987 & 0.010393 & $70.3681 \times 10^{-6}$ \\
\hline Hibiscetine & $\mathrm{Y}=4826.3 \mathrm{x}-1048.5$ & 0.9975 & 0.01242 & $59.6730 \times 10^{-6}$ \\
\hline Anthocyanins & $\mathrm{Y}=1943.7 \mathrm{x}+2908.5$ & 0.9974 & 0.011975 & $148.1710 \times 10^{-6}$ \\
\hline $\begin{array}{c}\text { Dephinidin-3- } \\
\text { glucoside }\end{array}$ & $\mathrm{Y}=2297.6 \mathrm{x}+1910.8$ & 0.9943 & 0.014 & $125.3481 \times 10^{-6}$ \\
\hline
\end{tabular}

\section{Mean concentration of antioxidants} in Calyces of Iraqi Hibiscus Sabdraffia Linn.

Table 4 shows the mean concentration of antioxidants for best separation from the calyces extract in ratio $(100 \%$ deionized water: $0 \%$ methanol). Triplicate measurement was done on the best extract sample.

Table 4: Mean Concentration of Antioxidants.

\begin{tabular}{|c|c|}
\hline Antioxidants & $\begin{array}{c}\text { Mean concentration } \pm \\
\mathrm{SD}(\mu \mathrm{g} / \mathrm{ml})\end{array}$ \\
\hline Vitamin C & $25.830 \pm 1.9$ \\
\hline Sabdaretine & $22.5510 \pm 2.0$ \\
\hline Gossypetine & $15.4975 \pm 1.8$ \\
\hline Hibiscetine & $11.1407 \pm 2.1$ \\
\hline Anthocyanins & $43.9442 \pm 1.7$ \\
\hline $\begin{array}{c}\text { Dephinidin-3- } \\
\text { glucoside }\end{array}$ & $18.5729 \pm 2.1$ \\
\hline
\end{tabular}

3. Concentration of Antioxidants in Dry Spacemen of Calyces of Hibiscus Sabdraffia Linn.

The following table 5 shows the concentrations of the substances which was studies by this research in the dry spacemen of calyces.

Table 5: Concentration of Antioxidants

\begin{tabular}{|c|c|}
\hline Antioxidants & $\begin{array}{c}\text { Concentration } \\
(\mu \mathrm{g} / \mathrm{g})\end{array}$ \\
\hline Vitamin C & 258.3 \\
\hline Sabdaretine & 225.51 \\
\hline Gossypetine & 154.975 \\
\hline Hibiscetine & 111.407 \\
\hline Anthocyanins & 439.442 \\
\hline $\begin{array}{c}\text { Dephinidin-3- } \\
\text { glucoside }\end{array}$ & 185.729 \\
\hline
\end{tabular}




\section{Conclusions:}

This proposed analytical method by RP- HPLC- Uv/ Vis for simultaneous separation and determination of six antioxidants naturally present in Hibiscus sabdraffia calyces was highly convenient for evaluation the level concentration of the compounds under study. The obtained results show also, that the Iraqi Hibiscus Sabdraffia calyces are rich in these compounds and can be used usefully for human consumption.

\section{References:}

1. Odebunmi, E. O.; Dosunmu, O. O. and Jedede, E. A. 2002. "Biophysico-chemical Analysis and Fermentation Studies of Hibiscus Sabdariffa", NJS. 30(1): 1-8.

2. Meza-Jiménez, J., J. Ramîrez, G. Luna-Solano, and I. GonzálezAndrade. 2009. "Low-cost solar thermodynamics drying system for the dehydration of Roselle (Hibiscus Sabdrariffa L.)". DRY TECHNOL.27: 621-624.

3. Fidan P., Nilüfer O. and Fatma E. 2011. "Studies on the Conformity of Hibiscus sabdariffa L. Samples from Turkish Market to European Pharmacopeia", FABAD J. Pharm. Sci., 36:25-32.

4. Morton, J. 1987. Roselle. p. 281286. In: Fruits of warm climates. Julia F. Morton, Miami, FL.

5. Christian, K. R.; Nair, M. G and Jackson, J. 2006. "Antioxidant and cyclooxygenase inhibitory activity of sorrel (Hibiscus sabdariffa)", $\mathrm{j}$ Food Comp Analysis. 19: 778-783.

6. Ali BH, Al-Wabel NA and Blunden G. 2005. "Phytochemical, pharmacological and toxicological aspects of Hibiscus sabdariffa L.: a review" Phytother Res. 19: 369-375.

7. Büyükblci, A., and S.N. EI.2008. "Determination of in vitro anti diabetic effects, antioxidant activities and phenol contents of some herbal tea". Plant Food Hum Nutr. 63: 27-33.

8. Norhaizan M., Fong SH., Amin I. and Chew LY. 2010. "Antioxidant activity in different parts of roselle (Hibiscus sabdariffa L.) extracts and potential exploitation of the seeds". Food Chem. 122: 1055-1060.

9. Vilasinee $\mathrm{H}$, Anocha $\mathrm{U}$, Noppawan PM, Nuntavan B, Angkana $\mathrm{H}$ and Chuthamanee $\mathrm{S}$. 2005. "Antioxidant Effect of aqueous extracts from dried calyces of Hibiscus sabdariffa L. (Roselle) in vitro using rat low-density lipoprotein(LDL)".Biol Pharm Bull. 28: 481-484.

10. Asolkar, L.V.; Kakkar, K. K and Chakre, O. J. 1992. Council of Scientific and Industrial Research, New Dalhi, India, pp.44.

11. Adnan W. Mohammed, Nadia F. Salman and Maison A A. Ahmed. 2011. "Histological study of the effect of Thyroxin and Aqueous extract of Karkade on liver in Swiss male mice". Magazin of Al- kufa University of Biology. 3: 1-9.

12. Venereo, G.J.R. 2002. "Dano oxidative, radicals libres $\mathrm{y}$

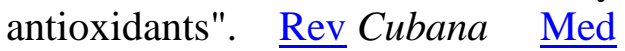
Militar. 31: 126-133.

13. Faudale, M., F. Viladomat, J. Bastide, F. Poli, and Codina. C. 2008. "Antioxidant activity and phenolic composition of wild, edible, and medicinal fennel from different Mediterranean countries". J. Agric. Food Chem. 56: 19121920.

14. Wilfred V. and Ralph N. 2006. " Phenolic Compound Biochemistry", P.18. Published by Springer.

15. Mahadevan, N., Shivali and Kamboj, P. 2009. "Hibiscus sabdariffa Linn. - An overview". NPR. 8: 77-83.

16. G. Venkatesh, M.I.A.Majid, S. Ramanthan. 2008. "Optimization 
and validation of RP-HPLC-UV method withsolid-phase extraction for determination of buparvaquone in human and rabbit plasma: application to pharmacokinetic study". Biomedical
17. Ijeomah, A. U., Ugwuona, F. U. and Abdullahi, H. 2012. "Phytochemical composition and antioxidant properties oh Hibiscus Sabdraffia and Moringa Oleifera". NJAFE. 8(1): 10- 16.

Chromatography. 22(5): 535- 541.

\section{أمثلة طريقة كرموتوغرافيا السائل عاليه الاداء- طور معاكس مع مطيافية الأشعة مونة

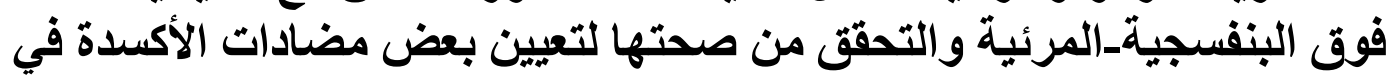 زهرة نبات الكجرات العراقي}

كريم دبيــة خلف *

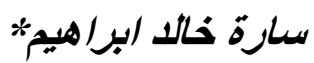 \\ *قنم الكيمياء، كلية العلوم للبنات، جامعة بغداد
}

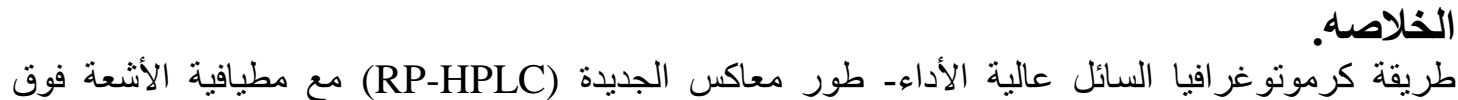

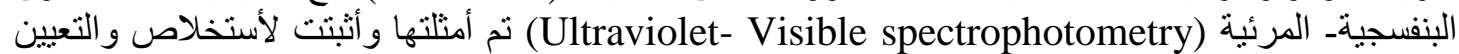
في وقت واحد لمضادات الأكسدة الموجودة في زهرة نبات الكجر ات العينة العر اقية.

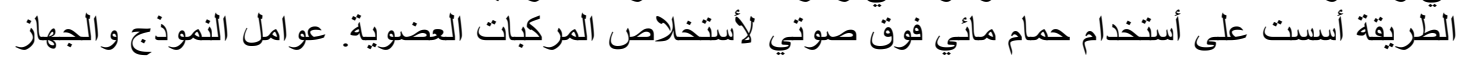

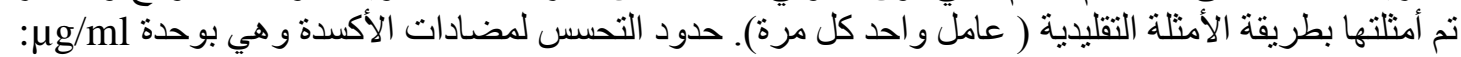
Vitamin C, Sabdaretine, Gossypetine, Hibiscetine, Anthocyanins, Dephinidin-3$10^{-6}, \times 10^{-6}, \quad 59.6730 \times 10^{-6}, \quad 70.3681 \times 10^{-6}, \quad 123.0453 \times$ glucoside were 113.8294 $10^{-6}$ respectively. $\times 10^{-6}$, and $125.3481 \times 148.1710$ تركيز مضادات الأكسدة التي تم در استها لنموذج زهرة الكجر ات الجافة هي كالاتي: Vitamin C, Sabdaretine, Gossypetine, Hibiscetine, Anthocyanins, and Dephinidin-3glucoside are $258.3 \mu \mathrm{g} / \mathrm{g}, 225.51 \mu \mathrm{g} / \mathrm{g}, 154.975 \mu \mathrm{g} / \mathrm{g}, 111.407 \mu \mathrm{g} / \mathrm{g}, 439.442 \mu \mathrm{g} / \mathrm{g}$, and $185.729 \mu \mathrm{g} / \mathrm{g}$ respectively. 